\title{
Bearing Capacity Characteristics of Steel Pipe Piles with Wings installed in Soil Cement Column
}

\author{
Pham Hoang Kien ${ }^{1, *}$ and Daisuke Ito $^{2}$ \\ ${ }^{1}$ University of Transport and Communications, Faculty of Civil Engineering, Hanoi, Vietnam \\ ${ }^{2}$ AsahiKasei Construction Materials Corporation, Tokyo, Japan
}

\begin{abstract}
The steel pipe piles with wings installed in soil cement developed in Japan and Vietnam are composite foundation piles made of steel pipes with wings with foundation improvement pillars in soil cement and spiral wings attached to the shaft intermittently. This composite pile has large vertical and horizontal bearing capacities and is a construction method of foundation piles with consideration of environments with little surplus soil, using steel pipes with small diameters. In this study, several full scale loading tests on steel pipe pile with wings installed in soil cement column are presented, and bearing capacity of the composite pile is studied. Especially, combination effect of soil cement column and steel pipe with wings on bearing capacity performance are discussed. Threedimensional elasto-plastic finite element analysis based on the results of loading tests to help understand this composite pile's mechanical characteristics is also performed.
\end{abstract}

\section{Introduction}

The steel pipe piles with wings installed in soil cement (from now referred to as ATT) have been developed in Japan and Vietnam. Up to now, there have been more than 5,000 cases of construction results. ATT is composite foundation piles made of steel pipes with wings with foundation improvement pillars (from now referred to as columns) in soil cement and spiral wings attached to the shaft intermittently. This composite pile provides large vertical and horizontal bearing capacities due to combination effect of soil cement column and steel pipe with spiral wings. ATT is also an environmentally friendly piling construction method with little surplus soil, low vibration and noise, using steel pipes with small diameters.

In Japan and Vietnam, there are many cases of weak ground where pile's support layer is very deep. In these cases, the piles become very long and problems have risen such as the cost for substructure becomes very high in comparison to the cost for superstructure. ATT is a foundation pile construction method developed to solve these kinds of problems. This is because ATT is a pile foundation developed as a friction pile with good cost performance, which does not become fixed to the support layer and displays bearing capacity by pile shaft friction.

\footnotetext{
*Corresponding author: phkien@utc.edu.vn
} 
In this study, several full scale loading tests of ATT are presented, and bearing capacity of the composite pile is studied. Especially, combination effect of soil cement column and steel pipe with spiral wings on bearing capacity performance are discussed. Threedimensional elasto-plastic finite element analysis based on the results of loading tests to help understand this composite pile's bearing characteristics is also performed.

\section{Standard Specifications of ATT}

The standard specifications of ATT's steel pipe with wings and column are shown in Fig.1 and Table 1. It is able to select from two to four types of wing diameter and column diameter for each steel pipe. Fig. 2 shows the toe shape of the steel pipe with wings. The end of the steel pipe is blocked by a steel plate, and there is a drilling blade on the end of the steel plate. Also, the pile head is blocked in the same way and inside of the steel pipe is hollow.

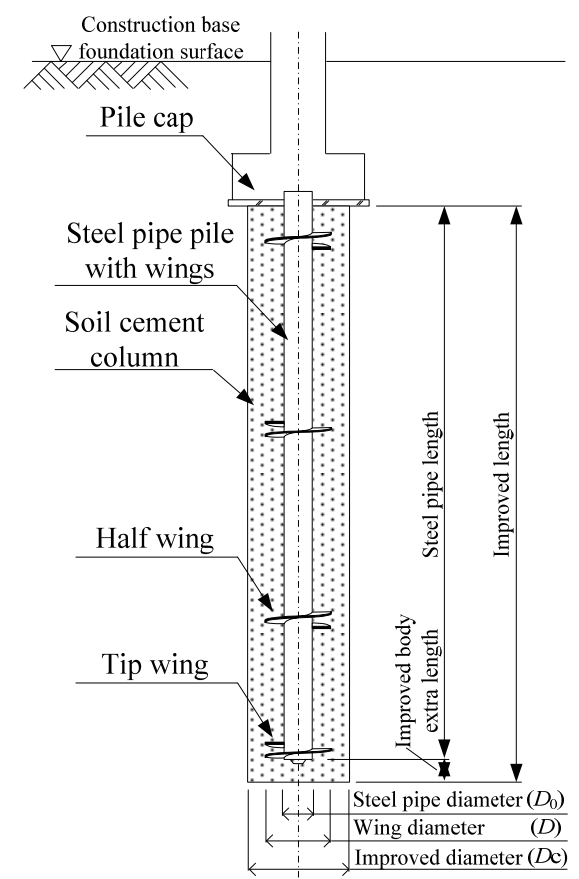

Fig. 1. Schematic drawing of the structure

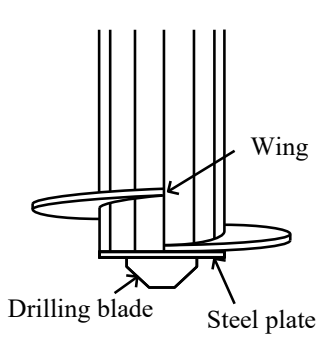

Fig. 2. Toe shape

\begin{tabular}{|c|c|c|c|c|c|c|c|c|c|}
\hline \multirow{2}{*}{ Wings $D(\mathrm{~mm})$} & \multirow{2}{*}{ Column $D_{\mathrm{c}}(\mathrm{mm})$} & \multicolumn{8}{|c|}{ Steel pipe $D_{0}(\mathrm{~mm})$} \\
\hline & & 114 & 139 & 165 & 190 & 216 & 267 & 318 & 355 \\
\hline 250 & \multirow{2}{*}{500} & 0 & 0 & & & & & & \\
\hline 300 & & 0 & 0 & 0 & & & & & \\
\hline 350 & \multirow{2}{*}{600} & 0 & $\mathrm{O}$ & 0 & 0 & & & & \\
\hline 400 & & & O & O & 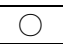 & 0 & & & \\
\hline 450 & \multirow{2}{*}{700} & & & 0 & $\mathrm{O}$ & 0 & 0 & & \\
\hline 500 & & & & & 0 & 0 & 0 & 0 & \\
\hline 600 & 900 & & & & & 0 & 0 & $\bigcirc$ & $\mathrm{O}$ \\
\hline 700 & 1000 & & & & & & 0 & $\mathrm{O}$ & 0 \\
\hline
\end{tabular}

\section{Vertical loading test in Hanoi}


The site for vertical loading test in Hanoi was situated approximately $15 \mathrm{~km}$ west from Hanoi's city center. Here, the influence of the existence of steel pipes with wings inserted into the column to the bearing capacity will be examined.

\subsection{Soil investigation}

Field work was carried out according to the British Standard (BS) 5930:1999 and the American Society for Testing and Materials (ASTM). Investigation results are shown in Fig. 3, Table 2 and Table 3 . The ground on which test specimens are placed is sandy silt with clay with SPT N-value of 0-4.

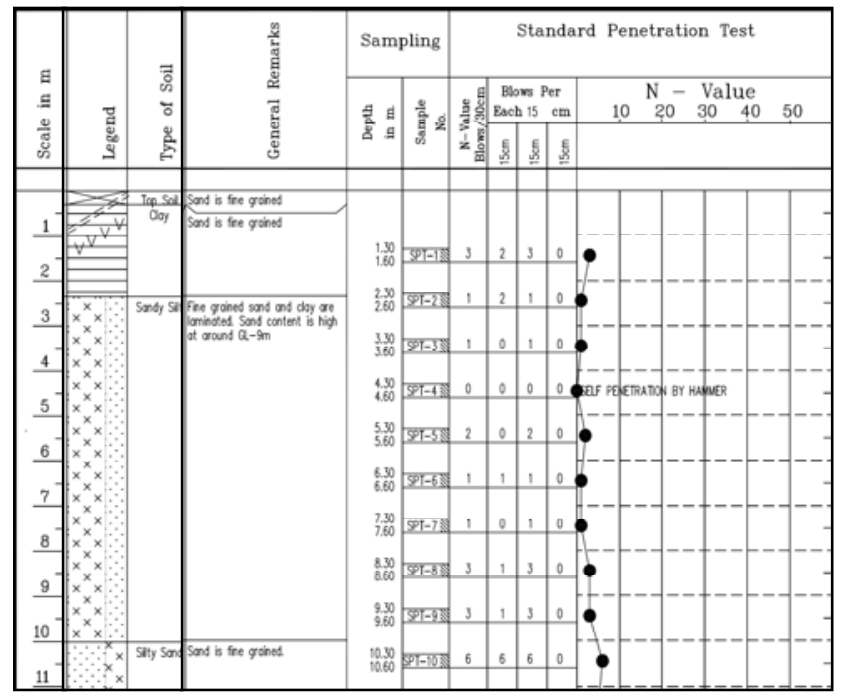

Fig. 3. SPT at Hanoi

Table 2. Index properties and unconfined compression test results

\begin{tabular}{|c|c|c|c|c|c|c|c|}
\hline \multirow[b]{2}{*}{$\begin{array}{l}\text { Depth. } \\
\text { (GL-m) }\end{array}$} & \multirow{2}{*}{$\begin{array}{c}\text { Natural Water } \\
\text { Content } \\
(\%)\end{array}$} & \multirow{2}{*}{$\begin{array}{c}\text { Wet } \\
\text { Density } \\
\left(\mathrm{Mg} / \mathrm{m}^{3}\right)\end{array}$} & \multicolumn{2}{|c|}{ Undisturbed } & \multicolumn{2}{|c|}{ Remolded } & \multirow{2}{*}{$\begin{array}{c}\text { Sensitivity } \\
\text { Ratio }\end{array}$} \\
\hline & & & $\begin{array}{c}q_{u} \\
(\mathrm{kPa})\end{array}$ & $\begin{array}{c}\varepsilon_{f} \\
(\%)\end{array}$ & $\begin{array}{c}q_{u} \\
(\mathrm{kPa})\end{array}$ & $\begin{array}{c}\mathcal{E f}_{f} \\
(\%)\end{array}$ & \\
\hline 2.00 to 2.80 & 34.0 & 1.88 & 51.5 & 9.2 & 20.2 & 19.9 & 2.5 \\
\hline 4.00 to 4.80 & 45.3 & 1.71 & 40.0 & 5.9 & 15.3 & 10.6 & 2.6 \\
\hline 6.00 to 6.80 & 40.7 & 1.78 & 46.7 & 6.4 & 13.0 & 13.5 & 3.6 \\
\hline 9.00 to 9.80 & 43.1 & 1.72 & 51.4 & 5.6 & 18.7 & 10.5 & 2.7 \\
\hline
\end{tabular}

Table 3. Consolidation test results

\begin{tabular}{|c|c|c|c|c|}
\hline $\begin{array}{c}\text { Depth } \\
\text { (GL-m) }\end{array}$ & $\begin{array}{c}\text { Initial void } \\
\text { ratio } \\
e_{o}\end{array}$ & $\begin{array}{c}\text { Preconsolidation } \\
\text { Pressure } \\
p_{c}(\mathrm{kPa})\end{array}$ & $\begin{array}{c}\text { Average Compression } \\
\text { Index } \\
\text { Ccave }\end{array}$ & $\begin{array}{c}\text { Swell Index } \\
\mathrm{Cr}\end{array}$ \\
\hline 4.00 to 4.80 & 1.621 & 110 & 0.56 & 0.12 \\
\hline
\end{tabular}

\subsection{Overview of vertical loading test in Hanoi}

Table 4 and Fig. 4 show an overview of the test specimens. N1, N2, and N4 had strain gauges attached to them to measure axial force distribution. Also, N1 and N2's columns were constructed $3 \mathrm{~m}$ from the pile head. To make each test results easier to compare, for $\mathrm{N} 5$, the column's surrounding ground was disrupted by mechanical stirring until GL-3m after column construction. The loading test was conducted after one month of test specimen curing period. The test method of multi-cycle complying with standard of JGS (Japan Geotechnical Society)'s “Method for Vertical Loading Test of Piles and Commentary" was 
used. As for N6, the aim was to reduce the surface friction resistance until GL-3m, and the column's surrounding ground was drilled until that depth right before the loading test, and then immediately re-buried, and the test was started.

Fig. 5 shows the uniaxial compression test results of the core specimen extracted from core boring. Deeper than GL-3m, $200 \mathrm{~kg} / \mathrm{m}^{3}$ of cement type solidifying substance was added. Shallower than GL-3m, in the loading tests of N5 and N6, double amount of 400kg/ $\mathrm{m}^{3}$ was added to prevent compression failure.

Table 4. Specifications of test pile

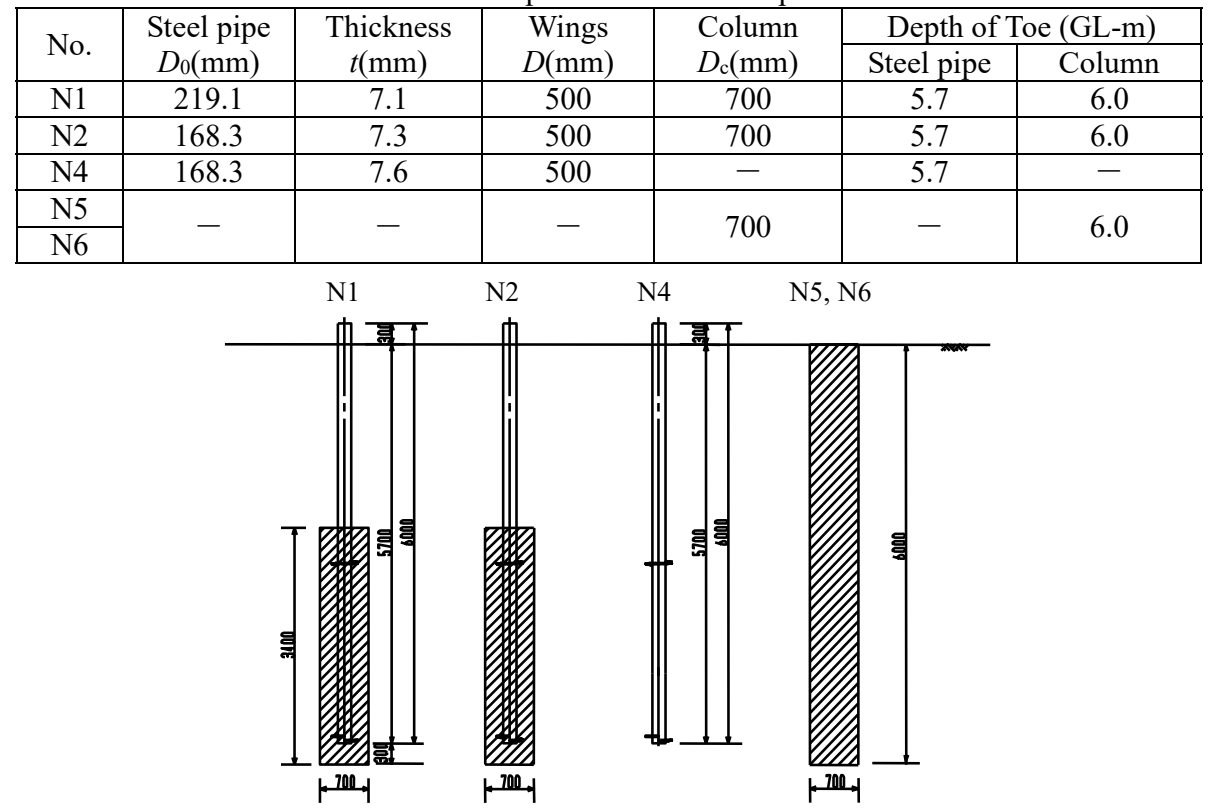

Fig. 4. Detailed diagram of test specimens

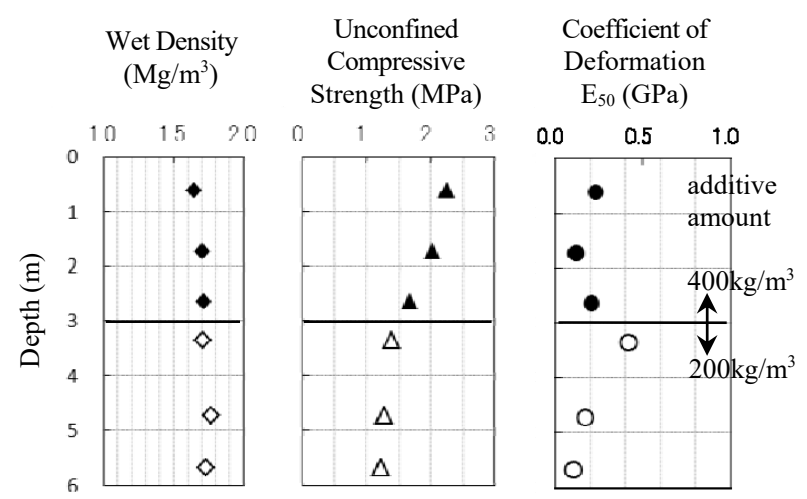

Fig. 5. Uniaxial compression test results

\subsection{Test results and discussions}

Fig.6 shows the pile head load - pile head settlement curve. (For the curves of N5 and N6's $P_{0}-S_{0}$, continuous measurement results after failure are plotted). The test specimens with steel pipes with wings (N1, N2, and N4) were able to maintain pile head load even at times of large deformation, and no significant decrease in pile head load was seen. On the other hand, test specimens with only a column $(\mathrm{N} 5, \mathrm{~N} 6)$ had drastically smaller loading capacities 
after exceeding pile head displacements N5 : $S_{0}=31 \mathrm{~mm}$, N6 : $S_{0}=13 \mathrm{~mm}$. This can be thought to be caused by compression failure within the column. As can be seen from Fig. 5 that the column's uniaxial compressive strength is approximately $1 \mathrm{Mpa}$ within the test interval, and the column cross section is $0.38 \mathrm{~m}^{2}$, therefore, the N6's test maximum load is valid. However, for N5 with the same specifications, it can be inferred that the test maximum load was greater than N6 and the surface friction resistance exhibited even in the shallow section, because although the column's surrounding ground was disturbed until GL-3m that ground recovered to a certain extent during the curing period.

From the test results of $\mathrm{N} 1$ and $\mathrm{N} 2$, there were no clear differences in load displacement curve due to differences in steel pipe diameter. This can be explained that the load capacity level was within the steel pipe's elastic deformity range and was small, the steel pipe, wings and column became one and were able to behave together, showing no significant differences in the results of the re-test of the column of the same specifications. Fig. 7 shows the axial force distribution of N2 and N4. The differences in test results are due to the existence and absence of columns. In the interval between the second cross section directly above the wing, and the fourth cross section on the end part, the surface friction degree evaluated from the wing diameter's cylindrical surface was $\tau_{N 2}=88 \mathrm{kN} / \mathrm{m}^{2}$ and $\tau_{N 4}=12.8 \mathrm{kN} / \mathrm{m}^{2}$ respectively, the result being approximately 7 times greater. The judgement of characteristic values was done from the load and displacement gained from the loading test. Table 5 shows the first limit resistance $P_{o y}$ and the second limit resistance $P_{o u}$ for each specimen. It can be seen from the test results of N1, N2, and N4, that the existence of columns has an effect of 4.2-5.3 times at the first limit resistance, and 3.6-3.9 times at the second limit resistance. From the results of N5 and N6, it can be concluded that the variety in column strength and quality greatly influenced the bearing capacity of the single body of the column.

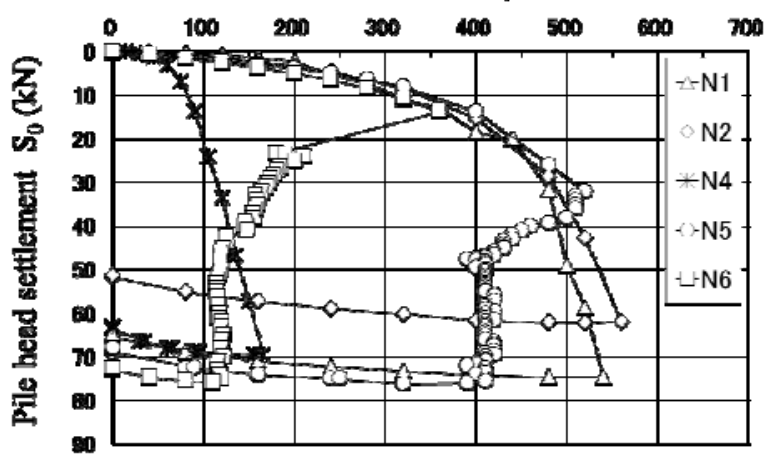

Fig. 6. Comparison of pile head load - pile head displacement
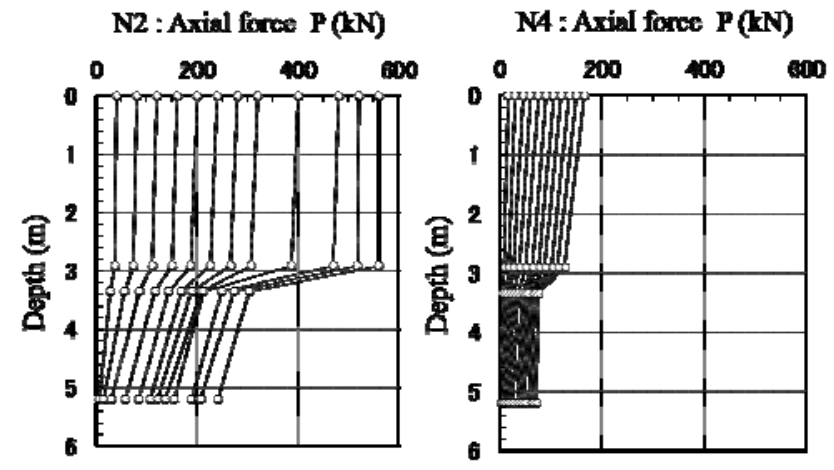

Fig. 7. Axial force distribution (N2, N4) 
Table 5. The characteristic values

\begin{tabular}{|c|c|c|c|c|c|}
\hline No. & $\begin{array}{l}\text { Steel pipe } \\
D_{0}(\mathrm{~mm})\end{array}$ & $\begin{array}{l}\text { Wings } \\
D(\mathrm{~mm})\end{array}$ & $\begin{array}{l}\text { Column } \\
D_{\mathrm{c}}(\mathrm{mm})\end{array}$ & $\begin{array}{l}\text { The first-limit-resistance } \\
\qquad P_{o v}(\mathrm{kN})\end{array}$ & $\begin{array}{l}\text { The second-limit-resistance } \\
P_{o u}(\mathrm{kN})\end{array}$ \\
\hline N1 & 219.1 & 500 & 700 & 400 & 509 \\
\hline $\mathrm{N} 2$ & 168.3 & 500 & 700 & 320 & 548 \\
\hline $\mathrm{N} 4$ & 168.3 & 500 & - & 75 & 141 \\
\hline N5 & \multirow{2}{*}{-} & \multirow{2}{*}{-} & 700 & 320 & 499 \\
\hline N6 & & & 700 & 270 & 343 \\
\hline
\end{tabular}

\section{Numerical analysis}

As shown by the loading test results, due to the combination effect between components of the composite pile, ATT provide greater bearing capacity compared to single body of column and single body of steel pipe with wings. In this section, contributions of column and steel pipe with wings to ATT bearing capacity will be investigated by numerical analysis.

\subsection{Analysis cases}

The analysis cases are shown in Table 6 and Fig. 8. The loading test carried out in Hanoi is used for finite element modeling of numerical analysis.

Table 6. Analysis cases

\begin{tabular}{|c|c|c|c|c|c|c|c|}
\hline & Loading test content & $\begin{array}{l}\text { Pile } \\
\text { No. }\end{array}$ & $\begin{array}{l}\text { Pile } \\
\text { length } \\
\text { (m) }\end{array}$ & $\begin{array}{c}\text { Steel pipe } \\
\text { diameter } \\
D_{0}(\mathrm{~mm})\end{array}$ & $\begin{array}{c}\text { Steel pipe } \\
\text { thickness } \\
t(\mathrm{~mm})\end{array}$ & $\begin{array}{l}\text { Wing } \\
\text { diameter } \\
D(\mathrm{~mm})\end{array}$ & $\begin{array}{c}\text { Column } \\
\text { diameter } \\
D_{\mathrm{c}}(\mathrm{mm})\end{array}$ \\
\hline Case-A_No.2 & ATT & No. 2 & \multirow[b]{2}{*}{6.0} & \multirow[b]{2}{*}{168.3} & 7.3 & \multirow[b]{2}{*}{500} & \multirow{3}{*}{700} \\
\hline Case-B_No.4 & $\begin{array}{l}\text { Single body of steel pipe } \\
\text { with wings }\end{array}$ & No.4 & & & 7.6 & & \\
\hline Case-C_No.6 & Single body of column & No.6 & - & - & - & - & \\
\hline
\end{tabular}

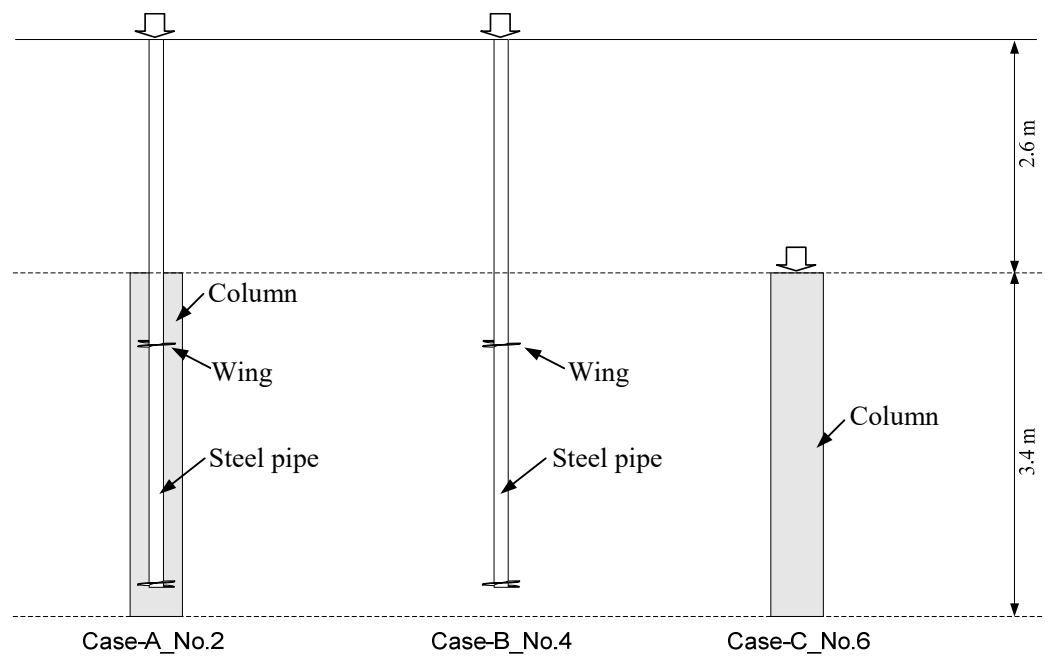

Fig. 8. Analysis cases

\subsection{Overview of numerical analysis}


Fig. 9 shows finite element modeling of Case-A_No.2. For this case, the number of nodes and elements is 20,727 and 18,400 , respectively.

In the numerical analysis, the ground is considered as elasto-plastic body using subloading $t_{i j}$ model. Soil properties of ground layers are shown in Table 7. Parameters of column and steel pipe with wings are shown in Table 8. Density and Young's modulus value of the column are obtained from compression test results of boring core specimens.
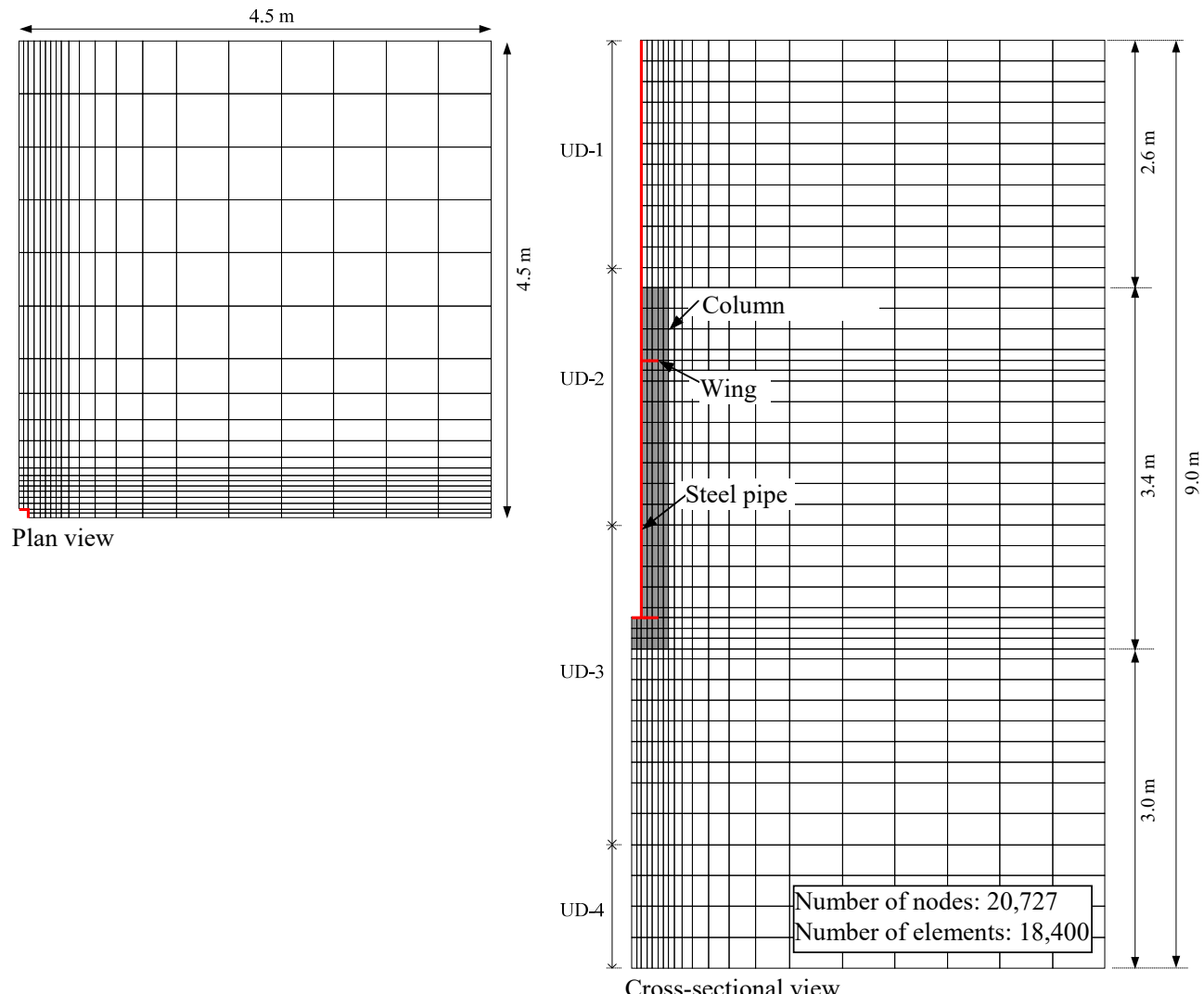

Fig. 9. Finite element modeling (Case-A No.2)

Table 7. Soil properties of ground layers

\begin{tabular}{|c|c|c|c|c|}
\hline \multirow{2}{*}{ Soil properties } & Clay & \multicolumn{3}{|c|}{ Sandy silt } \\
\cline { 2 - 5 } & $\begin{array}{c}\text { UD-1 } \\
(\text { G.L.-0.0 - } 2.4 \mathrm{~m})\end{array}$ & $\begin{array}{c}\text { UD-2 } \\
(\text { G.L.-2.4 -4.9 m) }\end{array}$ & $\begin{array}{c}\text { UD-3 } \\
\text { (G.L.-4.9 -7.8 m) }\end{array}$ & $\begin{array}{c}\text { UD-4 } \\
\text { (G.L.-7.8 -9.0 m) }\end{array}$ \\
\hline Plasticity index & 10 & 19 & 15 & 18 \\
\hline Density $\left(10^{3} \mathrm{~kg} / \mathrm{m}^{3}\right)$ & 1.880 & 1.710 & 1.780 & 1.720 \\
\hline Void ratio $e_{0}$ & 0.950 & 1.320 & 1.130 & 3.250 \\
\hline $\begin{array}{c}\text { Principal stress ratio at } \\
\text { critical state } M_{f}\end{array}$ & 3.728 & 3.009 & 3.310 & 0.300 \\
\hline Poisson ratio $v$ & 0.300 & 0.300 & 0.300 & 0.482 \\
\hline $\begin{array}{c}\text { Coefficient of earth } \\
\text { pressure at rest } K_{0}\end{array}$ & 0.423 & 0.488 & 0.464 & 1.5 \\
\hline$\beta \quad$ stress-dilatancy) & 1.5 & 1.5 & 1.5 & 500 \\
\hline a (ANN) parameter & 500 & 500 & 500 & 0.082 \\
\hline Compression index $\lambda$ & 0.091 & 0.243 & 0.117 & 0.011 \\
\hline Swelling index $\kappa$ & 0.018 & 0.052 & 0.020 & \\
\hline
\end{tabular}


Table 8. Parameters of column and steel pipe with wings

\begin{tabular}{|c|c|c|c|}
\hline & \multirow{2}{*}{$\begin{array}{c}\text { Steel pipe } \\
\text { and Wings }\end{array}$} & \multicolumn{2}{|c|}{ Column } \\
\cline { 3 - 4 } & & G.L.-2.6 - $4.9 \mathrm{~m}$ & G.L.-4.9 -6.0 m \\
\hline Density $\left(10^{3} \mathrm{~kg} / \mathrm{m}^{3}\right)$ & 7.850 & 1.73 & 1.73 \\
\hline Young's modulus $E\left(\mathrm{~N} / \mathrm{mm}^{2}\right)$ & $2.06 \times 10^{8}$ & 263.7 & 103.0 \\
\hline Poisson ratio $v_{0}$ & 0.300 & 0.298 & 0.298 \\
\hline
\end{tabular}

\subsection{Analytical results and discussions}

Relationship between vertical load and pile head settlement in the field experiment and numerical analysis is shown in Fig. 10. Axial force distribution of Case-A_No.2 at the first limit resistance is shown in Fig. 11. It can be seen here that a good accordance is obtained between the experimental and numerical analysis results. Displacement contour plots at the first limit resistance are shown in Fig. 12.

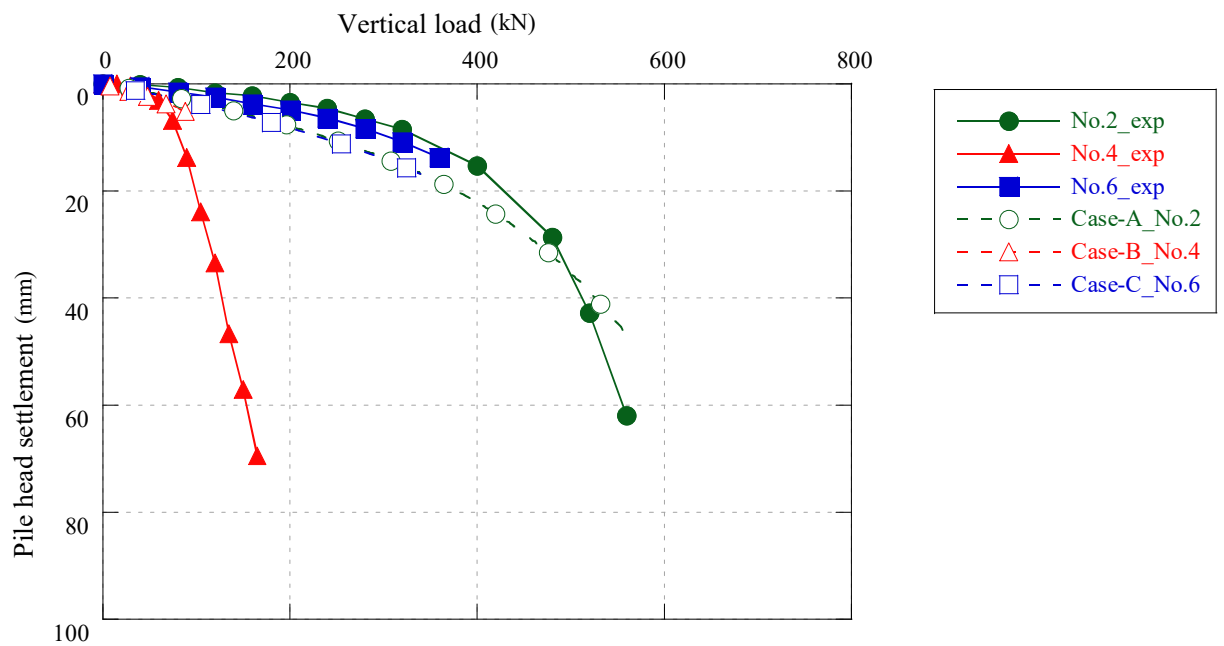

Fig. 10. Relationship between vertical load and pile head settlement
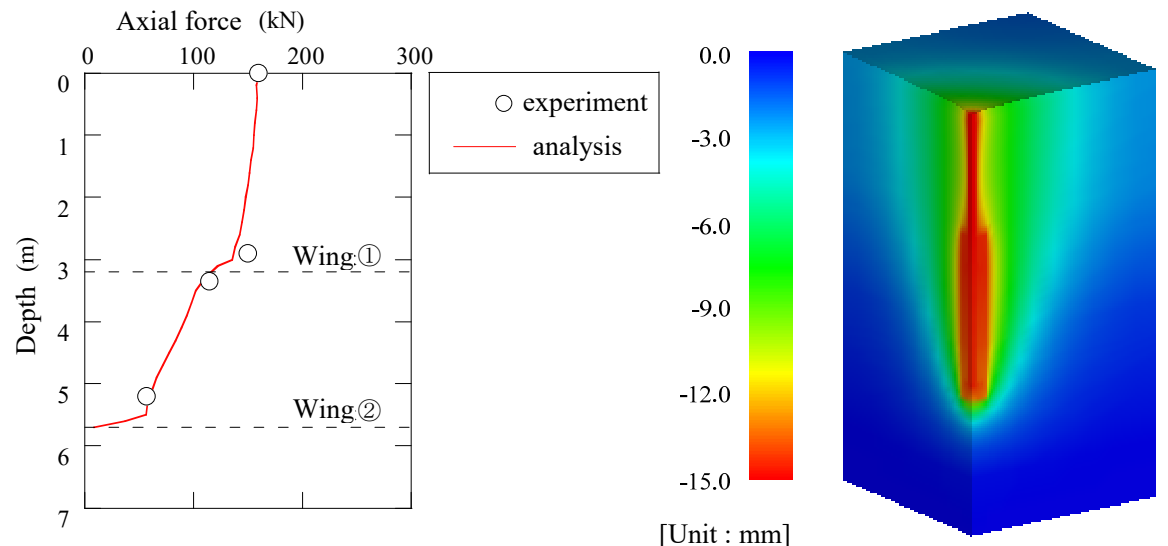

Fig. 11. Axial force distribution (Case-A_No.2 at the first limit resistance)

Fig. 12. Displacement contour plots (Case-A No.2 at the first limit resistance)

Fig. 13 shows vertical stress distribution of Case-A_No.2 (ATT) and Case-C_No.6 (single body of column) at the second limit resistance. In Fig. 13, the maximum value of vertical stress is taken as 1.0. Enlarged views of test specimen surrounding area are also shown in Fig. 13. 

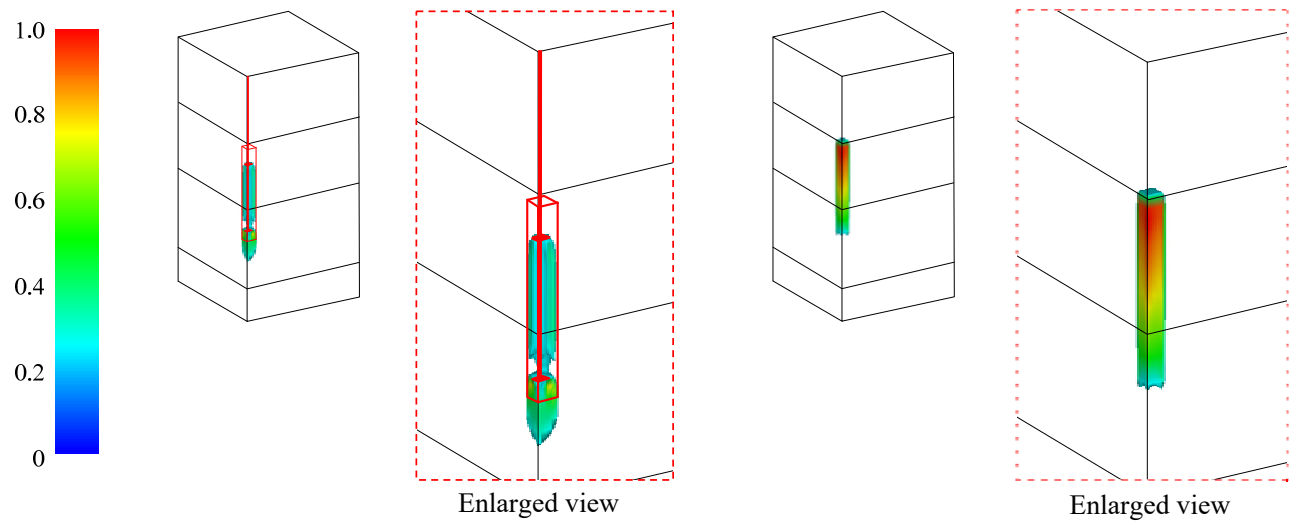

Fig. 13. Vertical stress distribution at the second limit resistance
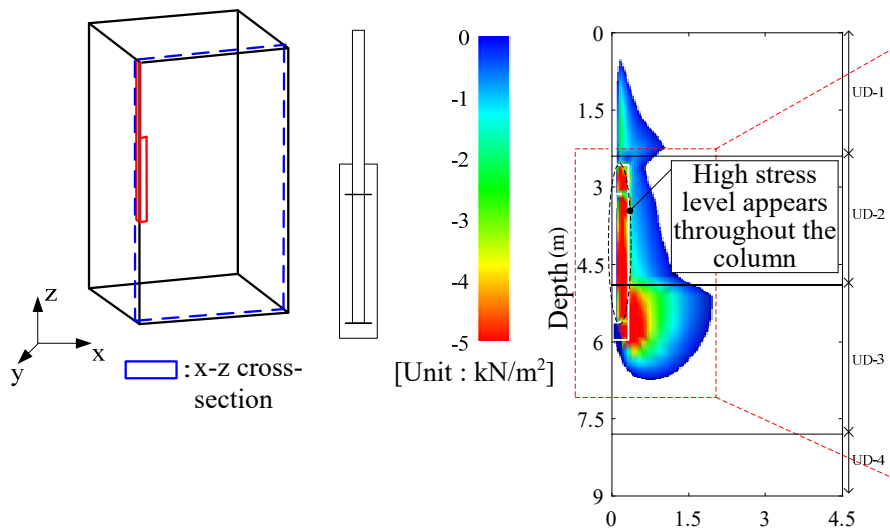

(a) Case-A_No.2 (ATT)
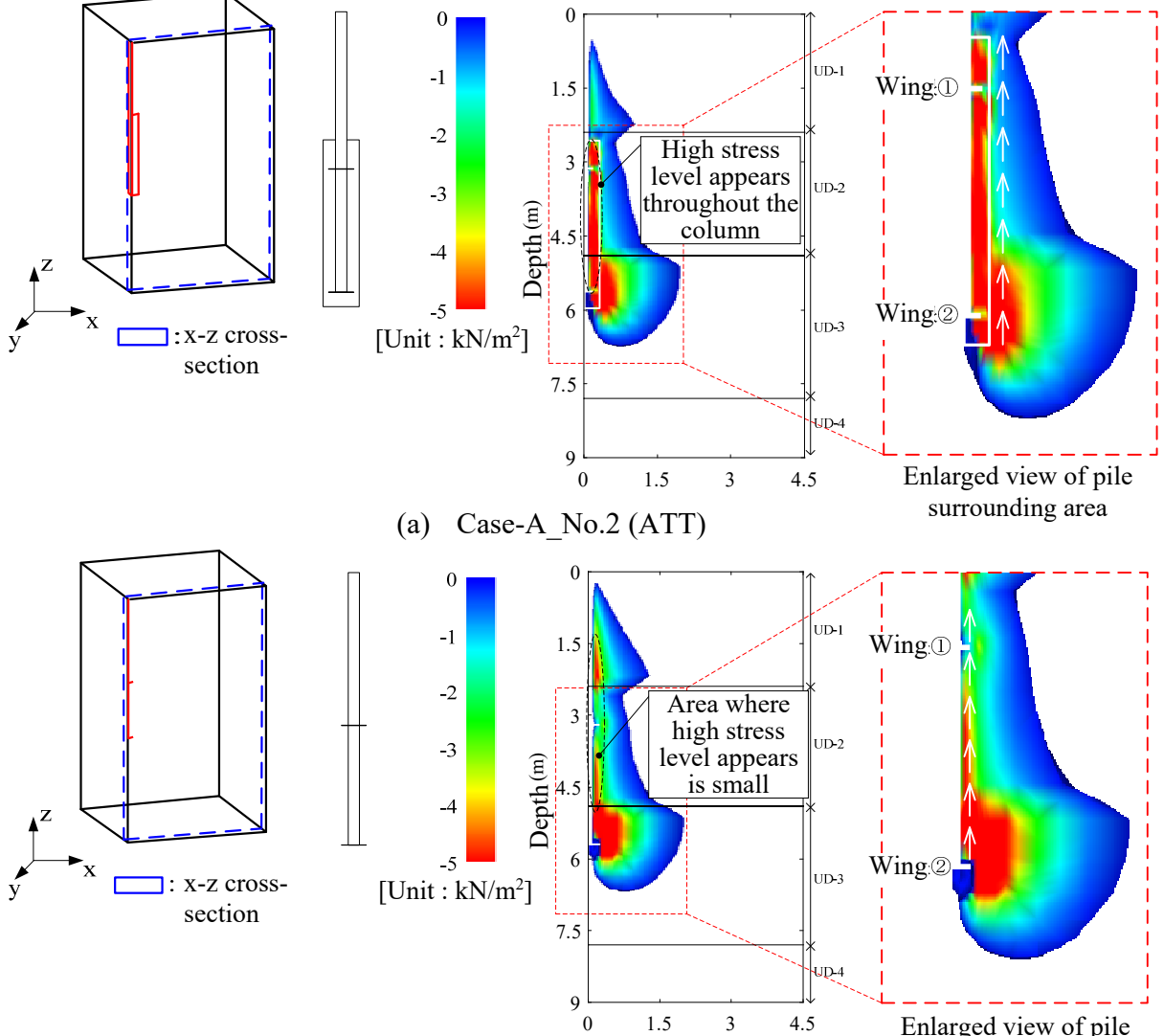

(b) Case-B_No.4 (Single body of steel pipe with wings)

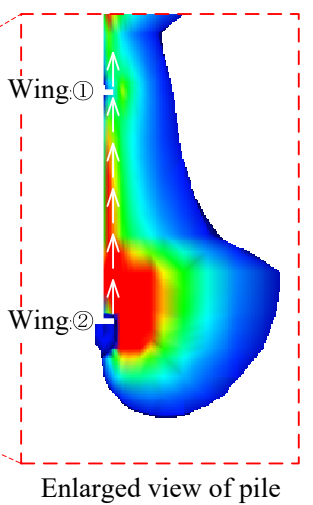

Fig. 14. Contour plots of shear stress $\tau_{x z}$ (test loading of $60 \mathrm{kN}$ )

It can be confirmed that for the case of Case-C_No.6 (column single body), stress concentration appeared at upper part of column. With increasing of vertical load during loading test, when the concentration stress becomes larger than column compression strength, compression failure will occur at upper part and the column will reach to its ultimate state. In contrast, for the case of Case-A_No.2 (ATT), high stress level does not appear at column head part and stress distribution in column overall is almost uniform, especially in the part of column under the wings. This means that the existence of steel pipe 
with wings helps distributing effectively the load acting on pile head to the column and the compression failure which occurs at upper part of column single body can be avoided.

Fig. 14 shows contour plots of shear stress $\tau_{x z}$ of Case-A_No.2 (ATT) and CaseB_No.4 (single body of steel pipe with wings). In both two cases, the load acting on steel pipe head is equal to the first limit resistance of Case-B_No.4 with the value of $60 \mathrm{kN}$. By comparison of shear stress distribution area in these two cases, it can be investigated on how the existence of column effects vertical bearing capacity characteristics. For CaseA_No.2 (ATT), high stress level appears throughout the column in a large area. This means that in the boundary between column and surrounding ground, friction force is exhibited and ATT has received resistance from surrounding ground. In contrast, for the case of Case-B_No.4 (single body of steel pipe with wings), area surrounding steel pipe with wings where high stress level appears is small and stress concentration occurs at area surrounding steel pipe end. It can be concluded that with the existence of column, large friction force with surrounding ground has mobilized and ATT exhibits larger bearing capacity compared to single body of steel pipe with wings.

\section{Conclusion}

In this study, full scale loading tests of ATT carried out in Hanoi are presented, and bearing capacity of the composite pile is studied. Especially, combination effect of soil cement column and steel pipe with spiral wings on bearing capacity performance are discussed. Three-dimensional elasto-plastic finite element analysis based on the results of loading tests to help understand this composite pile's bearing characteristics is also performed. Below is summary of the knowledge from this study:

1) It was confirmed that due to the combination effect, ATT composite pile can provide a greater vertical bearing capacity compared to the single body of column and single body of steel pipe with wings.

2) The existence of steel pipe with wings helps distributing effectively the load acting on pile head to the column and prevents the occurrence of stress concentration. Consequently, compression failure which occurs at upper part of column single body can be avoided.

3) With the existence of column in ATT, large friction force with surrounding ground has mobilized and ATT exhibits larger bearing capacity compared to single body of steel pipe with wings. It was found out that with the conditions of loading test introduced, approximately 4 times the bearing force was exerted.

4) It was confirmed that ATT composite pile is able to perform the same bearing capacity as in Japan in Vietnam's weak ground.

\section{References}

1. Japanese Geotechnical Society, Pile vertical load test method and explanation, First revised edition, 23-47 (2002).

2. H. Murakami, D. Ito, E. Mizoguchi, The Foundation Engineering \& Equipment, $A n$ application example of ATT Column construction method, Vol. 36(10), $72-75$ (2008).

3. T. Tamai, D. Ito, E. Mizoguchi, Japanese Geotechnical Society Journal, Study on the in-situ pile loading test and bearing capacity characteristics of steel pipe piles with wings installed in soil cement column, Vol. 4(4), 273-287 (2009).

4. B.D. Nguyen, H.K. Pham, 2016 International Conference on Sustainability in Civil Engineering (ICSCE 2016), A study of bearing capacity of steel pipe pile with wings installed in soil cement column in soft soil of Viet Nam, 283-288 (2016). 